\title{
Optimalisasi Peningkatan Hasil Belajar Siswa pada Tema Indahnya Kebersamaan Melalui Model Pembelajaran Jigsaw di Kelas IV.B SD Negeri 114/X Pandan Jaya
}

\author{
Adi Handoyo \\ SD Negeri 114/X Pandan Jaya \\ Jl. Hasanuddin, Pandan Jaya, Kec. Geragai, Kab. Tanjung Jabung Timur Prov. Jambi \\ Adihandoyo209@email.com
}

\begin{abstract}
This research aims to reveal information and discuss about Optimizing the Improvement of Student Learning Outcomes on the Theme of the Beauty of Togetherness Through the Jigsaw Learning Model in Class IV.B SD Negeri 114/X Pandan Jaya. This research is included in the type of Classroom Action Research (CAR). This research was carried out in this study was carried out at SD Negeri 114/X Pandan Jaya. The time of this research was carried out in the odd semester of the academic year 2021 - 2022, which began in July 2021. The subjects in this study were Class IV.B students, totaling 26 people. The research procedure consists of two cycles with four stages of research starting from planning, implementation, observation and reflection. Data collection in this study was carried out using observation sheets, field notes, learning outcomes test sheets, and documents. The data were analyzed using the percentage formula. The results of this study show that the Jigsaw learning model on the theme of the beauty of togetherness can improve student learning outcomes in class IV.B SD Negeri 114/X Pandan Jaya which is characterized by an increase from pre-cycle (27\%), cycle I (63\%), cycle II (85\%).
\end{abstract}

Keywords: Learning Outcomes, Jigsaw Learning Model

\begin{abstract}
Abstrak
Penelitian ini bertujuan untuk mengungkapkan informasi dan membahas tentang Optimalisasi Peningkatan Hasil Belajar Siswa pada Tema Indahnya Kebersamaan Melalui Model Pembelajaran Jigsaw di Kelas IV.B SD Negeri 114/X Pandan Jaya. Penelitian ini termasuk dalam jenis Penelitian Tindakan Kelas (PTK). Penelitian ini dilaksanakan di penelitian ini dilaksanakan di SD Negeri 114/X Pandan Jaya. Waktu penelitian ini dilaksanakan pada semester ganjil tahun pelajaran 2021 - 2022, yang dimulai pada bulan Juli 2021. Subjek dalam penelitian ini adalah siswa kelas IV.B yang berjumlah 26 orang. Prosedur penelitian terdiri dari dua siklus dengan empat tahap peneletian mulai dari perencanaan, pelaksanaan, observasi dan refleksi. Pengumpulan data dalam penelitian ini dilakukan dengan menggunakan lembar observasi, catatan lapangan, lembar tes hasil belajar, dan dokumen. Data dianalisis dengan menggunakan rumus persentase hasil penelitian ini menunjukkan bahwa melalui model pembelajaran jigsaw pada pada tema indahnya kebersamaan dapat meningkatkan hasil belajar siswa di kelas IV.B SD Negeri 114/X Pandan Jaya yang ditandai oleh meningkatnya dari pra siklus (27\%), siklus I (63\%), siklus II (85\%).
\end{abstract}

Kata Kunci : Hasil Belajar, Model Pembelajaran Jigsaw

Copyright (c) 2021 Adi Handoyo

Corresponding author: Adi Handoyo

Email Address: adihandoyo209@gmail.com (Jl. Hasanuddin, Pandan Jaya, Kec. Geragai, Jambi)

Received 01 December, Accepted 13 December 2021, Published 28 December 2021

\section{PENDAHULUAN}

Pemerintah memajukan ilmu pengetahuan dan teknologi dengan menjunjung tinggi nilai nilai agama dan persatuan bangsa untuk kemajuan peradapan kesejahteraan umat manusia (UUD 1945 Pasal 31 Ayat 5). Menurut UU Sisdiknas No. 20 Tahun 2003 Pasal 1 Ayat 1, Pendidikan adalah usaha sadar terencana untuk mewujudkan suasana belajar dan proses pembelajaran agar peserta didik secara 
aktif mengembangkan potensi dirinya untuk memiliki kekuatan spritual keagamaan, pengendalian diri, kepribadian, kecerdasan, akhlak mulia, serta keterampilan yang diperlukan dirinya, masyarakat, bangsa dan Negara.

Kurikulum 2013 menuntut adanya partisipasi aktif dari seluruh siswa. Jadi kegiatan belajar berpusat pada siswa, guru sebagai motivator dan fasilitator di dalamnya agar suasana kelas lebih hidup. Siswa yang saling menjelaskan pengertian suatu konsep pada temannya sedang mengalami proses belajar yang sangat efektif yang bisa memberikan hasil belajar yang jauh lebih maksimal daripada kalau dia mendengarkan penjelasan guru.

Salah satu masalah yang dihadapi dunia pendidikan kita adalah masalah lemahnya proses pembelajaran. Dalam proses pembelajaran, anak kurang didorong untuk mengembangkan kemampuan berpikir. Proses pembelajaran di dalam kelas diarahkan kepada kemampuan anak untuk menghafal informasi, otak anak dipaksa untuk mengingat dan menimbun berbagai informasi tanpa dituntut untuk memahami informasi yang diingatnya dan menghubungkannya dengan kehidupan sehari-hari, sehingga siswa cenderung pasif dalam kegiatan pembelajaran.

Usaha dalam pengembangan kegiatan pendidikan tersebut adalah meningkatkan mutu pendidikan, melengkapi sarana dan prasarana serta mengadakan pelatihan bagi guru. Hal ini diperlukan untuk mengembangkan kemampuan profesional dan membentuk watak serta peradaban bangsa yang bermatabat dalam rangka mencerdaskan kehidupan bangsa.

Namun berdasarkan data yang diperoleh pada siswa kelas IV SD Negeri 114/X Pandan Jaya masih banyak siswa yang di bawah KKM kurang dari (70) yaitu sebesar 73\% (19 orang) yang tidak tuntas, sedangkan yang mendapatkan nilai di atas KKM (70) yaitu sebesar 7\% (27 orang) yang tuntas dari 26 siswa dikelas IV.B SD Negeri 114/X Pandan Jaya.

Rendahnya hasil belajar siswa, diduga disebabkan oleh banyaknya siswa menggunakan bahasa daerah dalam proses pembelajaran. Selain itu, masih ada guru yang menggunakan model pembelajaran konvensional yaitu model ceramah. Hal tersebut dapat menyebabkan hasil belajar siswa menjadi rendah. Oleh karena itu, guru dituntut untuk memahami dan menerapkan beragam model pembelajaran, sehingga siswa lebih aktif dalam proses belajar. Salah satu model pembelajaran yang tepat pada pembelajaran yaitu model pembelajaran Jigsaw.

Sesuai dengan permasalahan diatas, maka tujuan penelitian tindakan kelas ini adalah untuk mengetahui dan mendapatkan informasi tentang Optimalisasi Peningkatan Hasil Belajar Siswa Pada Tema Indahnya Kebersamaan Melalui Model Pembelajaran Jigsaw Di Kelas IV.B SD Negeri 114/X Pandan Jaya.

Pembelajaran pada hakekatnya merupakan proses interaksi antar anak dengan anak, anak dengan sumber belajar, dan anak dengan pendidikan. Kegiatan pembelajaran ini akan menjadi bermakna bagi anak jika dilakukan dalam lingkungan yang nyaman dan memberikan rasa aman bagi anak. Proses belajar secara individual dan kontekstual, artinya proses belajar terjadi dalam diri individu sesuai dengan perkembangan dan lingkungannya. 
Belajar bermakna suatu proses dikaitkannya informasi baru pada konsep-konsep relevan yang terdapat dalam struktur kognitif seseorang. Belajar adalah modifikasi atau memperteguh kelakuan melalui pengalaman (learning is defined the modification or streng modifcation or strenghening of behavior through experiencing). Menurut pengertian ini, belajar merupakan proses, suatu kegiatan bukan suatu hasil atau tujuan. Belajar bukan hanya mengingat, akan tetapi lebih luas dari itu yakni mengalami. Hasil belajar bukan hanya mengingat suatu penguasaan hasil latihan melainkan pengubahan kelakuan (Hamalik, 2004).

Dari pendapat para ahli diatas dapat disimpulkan bahwa belajar adalah suatu proses perubahan tingkah laku yang sedang berlangsung secara bertahap yang terjadi sebagai suatu hasil dari latihan dan pengalaman.

Menurut Hariyanto (2012 : 19) Belajar adalah suatu aktivitas atau suatu proses untuk memperoleh pengatahuan, meningkatkan keterampilan memperbaiki prilaku sikap dan mengkokohkan kepribadian. Menurut Agus (2012:3) Learning is any relatively permanent change in behavior that is a result of past experience. (Belajar adalah perubahan perilaku yang bersifat permanen sebagai hasil dari pengalaman). Kemudian hasil belajar adalah pola-pola perbuatan, nilai-nilai, pengertianpengertian, sikap-sikap, apresiasi, abilitas, dan keterampilan. Dari beberapa pendapat di atas dapat disimpulkan bahwa belajar adalah suatu proses untuk memperoleh perubahan perilaku yang bersifat permanen sebagai hasil dari pengalaman.

Hasil belajar seorang siswa biasanya dinyatakan dengan angka kemudian dapat dideskripsikan. Untuk mendapatkan nilai tersebut dilakukan penilaian. Penilaian merupakan sebagai alat untuk mengetahui keberhasilan proses pembelajaran yang terjadi antara pendidik dan peserta didik. Penilaian kegiatan belajar dapat dilakukan dengan suatu alat evaluasi berupa tes dan non tes. Menurut Nana (2002:22) hasil belajar merupakan "Kemampuan-kemampuan yang dimiliki siswa setelah ia menerima pengalaman belajar".

Dari beberapa pendapat diatas tentang hasil belajar dapat disimpulkan bahwa hasil belajar merupakan tingkat perkembangan mental yang lebih baik bila dibandingkan pada saat sebelum belajar berupa perubahan tingkah laku yang terjadi sesudah proses belajar baik kognitif, afektif maupun psikomotor.

Menurut Agus Suprijono (2010:46) Model pembelajaran ialah pola yang digunakan sebagai pedoman dalam merencanakan pembelajaran dikelas maupun tutorial. Menurut Arends, model pembelajaran mengacu pada pendekatan yang akan digunakan, termasuk didalamnya tujuan-tujuan pembelajaran, tahap-tahap dalam kegiatan pembelajaran, lingkungan pembelajaran, dan pengelolaan kelas. Melalui model pembelajaran guru dapat membantu peserta didik mendapatkan informasi, ide, keterampilan, cara berfikir, dan mengekspresikan ide. Model pembelajaran berfungsi pula sebagai pedoman bagi para perancang pembelajaran dan para guru dalam merencanakan aktivitas belajar mengajar. 
Model pembelajaran kooperatif model jigsaw adalah sebuah model belajar kooperatif yang menitik beratkan kepada kerja kelompok siswa dalam bentuk kelompok kecil, seperti yang diungkapkan Lie (1993:73), bahwa pembelajaran kooperatif model jigsaw ini merupakan model belajar kooperatif dengan cara siswa belajar dalam kelompok kecil yang terdiri atas empat sampai dengan enam orang secara heterogen dan siswa bekerja sama saling ketergantungan positif dan bertanggung jawab secara mandiri. Dalam model pembelajaran jigsaw ini siswa memiliki banyak kesempatan untuk mengemukakan pendapat, dan mengelolah informasi yang didapat dan dapat meningkatkan keterampilan berkomunikasi, anggota kelompok bertanggung jawab atas keberhasilan kelompoknya dan ketuntasan bagian materi yang dipelajari, dan dapat menyampaikan kepada kelompoknya (Rusman, 2010.203).

Menurut Slavin (2007), pembelajaran kooperatif menggalakan siswa berinteraksi secara aktif dan positif dalam kelompok. Ini membolehkan pertukaran ide dan pemeriksaaan ide sendiri dalam suasana yang tidak terancam, sesuai dengan falsafah konstruktivisme. Dengan demikian, pendidikan hendaknya mampu mengkondisikan dan memberikan dorongan untuk dapat mengoptimalkan dan membangkitkan potensi siswa, menumbuhkan aktivitas dan daya cipta kreativitas sehingga akan menjamin terjadinya dinamika di dalam proses pembelajaran.

\section{METODE}

Penelitian ini termasuk dalam jenis penelitian tindakan kelas (PTK). Penelitian ini dilaksanakan di Penelitian ini dilaksanakan di SD Negeri 114/X Pandan Jaya. Waktu penelitian ini dilaksanakan pada semester ganjil tahun pelajaran 2021 - 2022, yang dimulai pada bulan Juli 2021. Subjek dalam penelitian ini adalah siswa kelas IV.B yang berjumlah 26 orang. Prosedur penelitian terdiri dari dua siklus dengan empat tahap peneletian mulai dari perencanaan, pelaksanaan, observasi dan refleksi. Pengumpulan data dalam penelitian ini dilakukan dengan menggunakan lembar observasi, catatan lapangan, lembar tes hasil belajar, dan dokumen. Data dianalisis dengan menggunakan rumus persentase.

\section{HASIL DAN DISKUSI}

\section{Paparan Data Pra Siklus}

Pra siklsus merupakan kondisi awal siswa sebelum peneliti melakukan kegiatan penelitian di dalam kelas, dengan menggunakan pola pembelajaran konvensional. Selanjutnya, berdasarkan hasil data Pra Siklus yang diperoleh, peneliti bersama guru lain melakukan evaluasi mengenai metode/model pembelajaran yang dianggap tepat, sebagai bentuk tindakan perbaikan dari proses pembelajaran. Kegiatan pengambilan data Pra siklus dilakukan di Kelas IV.B SD Negeri 114/Pandan Jaya dengan jumlah siswa 26 orang. Prasiklus di lakukan peneliti dengan cara melaksanakan kegiatan pembelajaran dengan menggunakan model tanya jawab yang diakhiri dengan pelaksanaan tes. Dampaknya hasil belajar siswa juga rendah, ini dibukti dari hasil ulangan harian terakhir sebelum 
model yang diterapkan dengan nilai tertinggi data selengkapnya, dapat dilihat pada tabel di bawah ini:

Tabel 1. Rekapitulasi Hasil Belajar Siswa Pra Siklus

\begin{tabular}{|c|c|c|c|}
\hline No & Nama Siswa & Nilai & Keterangan \\
\hline 1 & Achmad Rafa Saputra & 60 & Tidak Tuntas \\
\hline 2 & Aishka Vybie Azzahra & 65 & Tidak Tuntas \\
\hline 3 & Aliyah Nur Zahira & 75 & Tuntas \\
\hline 4 & Atania Miracle Christie Br S.Depari & 70 & Tuntas \\
\hline 5 & Bayu Andika Pratama & 65 & Tidak Tuntas \\
\hline 6 & Bintang Syafani & 65 & Tidak Tuntas \\
\hline 7 & Fairel Athariss Calief & 70 & Tuntas \\
\hline 8 & Gina Rinehart & 60 & Tidak Tuntas \\
\hline 9 & Irza Aldiansyah & 70 & Tuntas \\
\hline 10 & Kamilah Mutlihah & 65 & Tidak Tuntas \\
\hline 11 & Khalisa Hayu Nazeeha & 65 & Tidak Tuntas \\
\hline 12 & L. Berlian Natasya & 70 & Tuntas \\
\hline 13 & M. Fairusmansyur & 70 & Tuntas \\
\hline 14 & M. Nasuha.St & 65 & Tidak Tuntas \\
\hline 15 & Maria Ulfah & 60 & Tidak Tuntas \\
\hline 16 & Mei Syifa Irwansyah & 65 & Tidak Tuntas \\
\hline 17 & Monica Rachel Adelia Putri & 65 & Tidak Tuntas \\
\hline 18 & Muhammad Asri & 60 & Tidak Tuntas \\
\hline 19 & Mutiara Septiani & 65 & Tidak Tuntas \\
\hline 20 & Nathasya Aulia Putri & 65 & Tidak Tuntas \\
\hline 21 & Puspa Safatri Monik & 60 & Tidak Tuntas \\
\hline 22 & Rabbani Al Fathan & 65 & Tidak Tuntas \\
\hline 23 & Raka Rafael Manulang & 65 & Tidak Tuntas \\
\hline 24 & Raziq Zharfan Ramadhan & 70 & Tuntas \\
\hline 25 & Reysha Dwi Saputri & 65 & Tidak Tuntas \\
\hline 26 & Soraya Karisa Putri & 60 & Tidak Tuntas \\
\hline \multicolumn{2}{|c|}{ Jumlah } & 1700 & \\
\hline \multicolumn{2}{|c|}{ Rata-Rata } & 65,4 & \\
\hline \multicolumn{2}{|c|}{ KKM } & 70 & \\
\hline \multicolumn{2}{|c|}{ Jumlah Siswa Yang Tuntas } & \multicolumn{2}{|c|}{7 Orang $/ 27 \%$} \\
\hline \multicolumn{2}{|c|}{ Jumlah Siswa Yang Belum Tuntas } & \multicolumn{2}{|c|}{19 Orang $/ 73 \%$} \\
\hline
\end{tabular}

Dari tabel di atas dapat dijelaskan bahwa sebelum menerapkan Model pembelajaran Jigsaw di peroleh rata - rata hasil belajar siswa yaitu 65,4 dengan presentase $27 \%$ atau 7 siswa dari 26 orang yang tuntas belajar. Hasil tersebut menunjukkan bahwa pada pra siklus secara klasikal siswa belum tuntas belajar, karena hanya 7 siswa yang memperoleh nilai $\geq 70$ atau hanya sebesar $27 \%$ yang mencapai kriteria ketuntasan minimum (KKM). Sehingga, masih terdapat 19 dari 26 siswa yang belum tuntas belajar atau sebanyak 73\%. Hasil tersebut lebih kecil dari presentase ketuntasan klasikal dalam proses pembelajaran yang dikehendaki sebesar $80 \%$. Berdasarkan tabel nilai dan penjelasan nilai pra siklus diatas dapat dilihat lebih jelas pada diagram dibawah ini: 


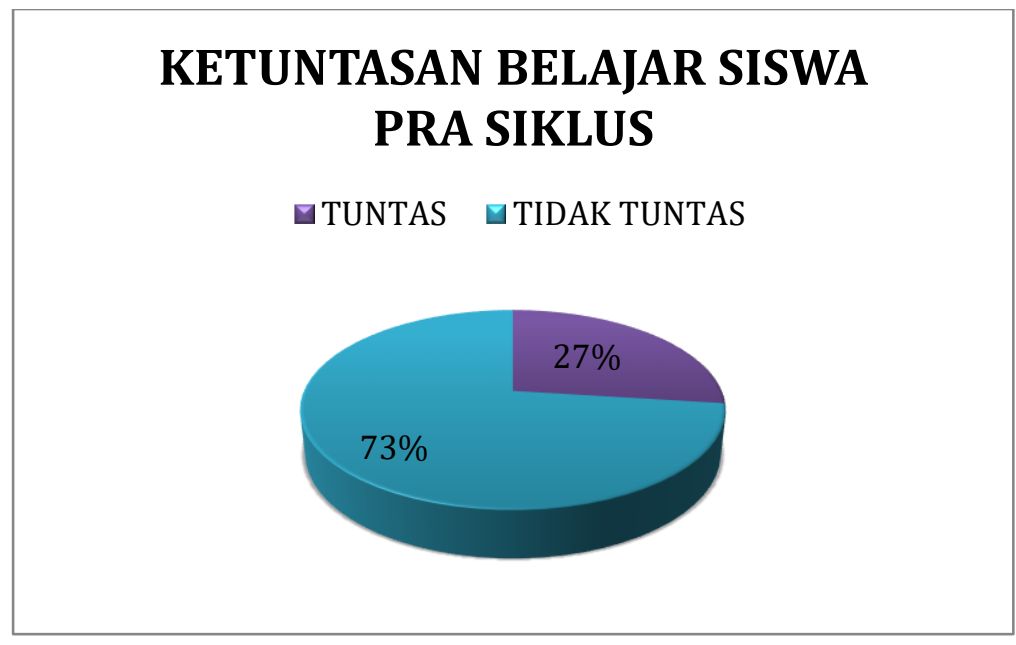

Gambar 1. Diagram Ketuntasan Nilai Pra Siklus

Berdasarkan kenyataan di atas, peneliti dibantu oleh teman sejawat (Yetti, S.Pd) melakukan kajian dan telaah yang akan dipergunakan sebagai dasar pertimbangan memilih strategi pembelajaran yang tepat, dalam upaya melakukan tindakan perbaikan pembelajaran. Setelah berdiskusi dan mempertimbangkan berbagai alasan tersebut, peneliti memilih Model pembelajaran Jigsaw. Model ini dipergunakan dalam PTK yang akan dilaksanakan pada saat berlangsungnya proses pembelajaran di Kelas IV.B SD Negeri 114/X Pandan Jaya, yang diharapkan dapat meningkatkan hasil belajar pada siswa kelas tersebut.

\section{Hasil Penelitian}

\section{Siklus I}

\section{Perencanaan}

Pada tahap ini peneliti mempersiapkan perangkat pembelajaran yang terdiri dari silabus, RPP, buku paket, LKS, serta instrumen yang digunakan sesuai dengan model pembelajaran yang ingin diterapkan. Lalu menyiapkan dokumen onservasi, lembar observasi hasil belajar siswa, perolehan hasil belajar siswa UH 1.

\section{Pelaksanaan}

Pertemuan pertama di siklus I dilaksanakan pada hari rabu tanggal 21 Juli 2021 tahun pelajaran 2021/2022 jam pelajaran 1-2 di kelas IV.B dengan jumlah siswa 26 orang. Adapun materi pembelajaran pada pertemuan pertama ini adalah indahnya kebersamaan. Pada kegiatan pembelajaran, peneliti melaksanakan berdasarkan rencana pelaksanaan pembelajaran (RPP). Guru memulai dengan memberikan apersepsi berupa mengingatkan kembali pelajaran terdahulu dan memberikan motivasi mengenai pentingnya mempelajari materi serta mengaitkannya dengan kegiatan sehari-hari. Pada pertemuan pertama siklus I ini penelitian mengacu pada prosedur yang telah ditetapkan mulai dari kegiatan pendahuluan, kegiatan inti dan kegiatan penutup.

Pertemuan kedua disiklus I dilaksanakan pada hari kamis tanggal 22 Juli 2021 jam pelajaran 3-4 di kelas IV.BS dengan jumlah siswa 26 orang. Adapun materi pembelajaran pada pertemuan kedua ini adalah indahnya kebersamaan. Pada kegiatan pembelajaran, peneliti melaksanakan 
berdasarkan rencana pelaksanaan pembelajaran (RPP). Guru memulai dengan memberikan apersepsi berupa mengingatkan kembali pelajaran terdahulu dan memberikan motivasi mengenai pentingnya mempelajari materi serta mengaitkannya dengan kegiatan sehari-hari. Pada pertemuan kedua siklus I ini penelitian mengacu pada prosedur yang telah ditetapkan mulai dari kegiatan pendahuluan, kegiatan inti dan kegiatan penutup.

\section{Observasi}

Pengamatan (observasi) dilaksanakan bersamaan dengan pelaksaaan belajar mengajar yang dilakukan oleh observer. Adapun yang diamati oleh Observer meliputi pengelolaan belajar mengajar guru, aktivitas guru dan aktivitas siswa selama proses pembelajaran. Pada akhir proses belajar mengajar siswa diberi tes formatif dengan tujuan untuk mengetahui tingkat keberhasilan siswa dalam proses belajar mengajar yang telah dilakukan. Adapun data hasil penelitian pada siklus I adalah sebagai berikut:

Tabel 2. Rekapitulasi Hasil Belajar Siswa Siklus I

\begin{tabular}{|c|c|c|c|}
\hline No & Nama Siswa & Nilai & Keterangan \\
\hline 1 & Achmad Rafa Saputra & 67 & Tidak Tuntas \\
\hline 2 & Aishka Vybie Azzahra & 68 & Tidak Tuntas \\
\hline 3 & Aliyah Nur Zahira & 80 & Tuntas \\
\hline 4 & Atania Miracle Christie Br S.Depari & 80 & Tuntas \\
\hline 5 & Bayu Andika Pratama & 80 & Tuntas \\
\hline 6 & Bintang Syafani & 85 & Tuntas \\
\hline 7 & Fairel Athariss Calief & 85 & Tuntas \\
\hline 8 & Gina Rinehart & 65 & Tidak Tuntas \\
\hline 9 & Irza Aldiansyah & 80 & Tuntas \\
\hline 10 & Kamilah Mutlihah & 70 & Tuntas \\
\hline 11 & Khalisa Hayu Nazeeha & 75 & Tuntas \\
\hline 12 & L. Berlian Natasya & 80 & Tuntas \\
\hline 13 & M. Fairusmansyur & 85 & Tuntas \\
\hline 14 & M. Nasuha.St & 75 & Tuntas \\
\hline 15 & Maria Ulfah & 63 & Tidak Tuntas \\
\hline 16 & Mei Syifa Irwansyah & 75 & Tuntas \\
\hline 17 & Monica Rachel Adelia Putri & 80 & Tuntas \\
\hline 18 & Muhammad Asri & 65 & Tidak Tuntas \\
\hline 19 & Mutiara Septiani & 75 & Tuntas \\
\hline 20 & Nathasya Aulia Putri & 75 & Tuntas \\
\hline 21 & Puspa Safatri Monik & 65 & Tidak Tuntas \\
\hline 22 & Rabbani Al Fathan & 75 & Tuntas \\
\hline 23 & Raka Rafael Manulang & 80 & Tuntas \\
\hline 24 & Raziq Zharfan Ramadhan & 80 & Tuntas \\
\hline 25 & Reysha Dwi Saputri & 68 & Tidak Tuntas \\
\hline 26 & Soraya Karisa Putri & 65 & Tidak Tuntas \\
\hline \multicolumn{2}{|c|}{ Jumlah } & 1941 & \\
\hline \multicolumn{2}{|c|}{ Rata-Rata } & 74,7 & \\
\hline \multicolumn{2}{|c|}{ KKM } & 70 & \\
\hline \multicolumn{2}{|c|}{ Jumlah Siswa Yang Tuntas } & \multicolumn{2}{|c|}{18 Orang $/ 69 \%$} \\
\hline \multicolumn{2}{|c|}{ Jumlah Siswa Yang Belum Tuntas } & \multicolumn{2}{|c|}{8 Orang $/ 31 \%$} \\
\hline
\end{tabular}


Dari tabel di atas dapat dijelaskan bahwa Pada siklus I ini di peroleh rata - rata hasil belajar siswa yaitu 74,7 dengan presentase 69\% atau 18 siswa dari 26 orang yang tuntas belajar. Hasil tersebut menunjukkan bahwa pada siklus I secara klasikal siswa belum tuntas belajar, karena hanya 18 siswa yang memperoleh nilai $\geq 70$ atau hanya sebesar $69 \%$ yang mencapai kriteria ketuntasan minimum (KKM).

Sehingga, masih terdapat 8 dari 26 siswa yang belum tuntas belajar atau sebanyak $31 \%$. Hasil tersebut lebih kecil dari presentase ketuntasan klasikal dalam proses pembelajaran yang dikehendaki sebesar $80 \%$. Berdasarkan tabel nilai dan penjelasan nilai dari siklus I diatas dapat dilihat lebih jelas pada diagram dibawah ini:

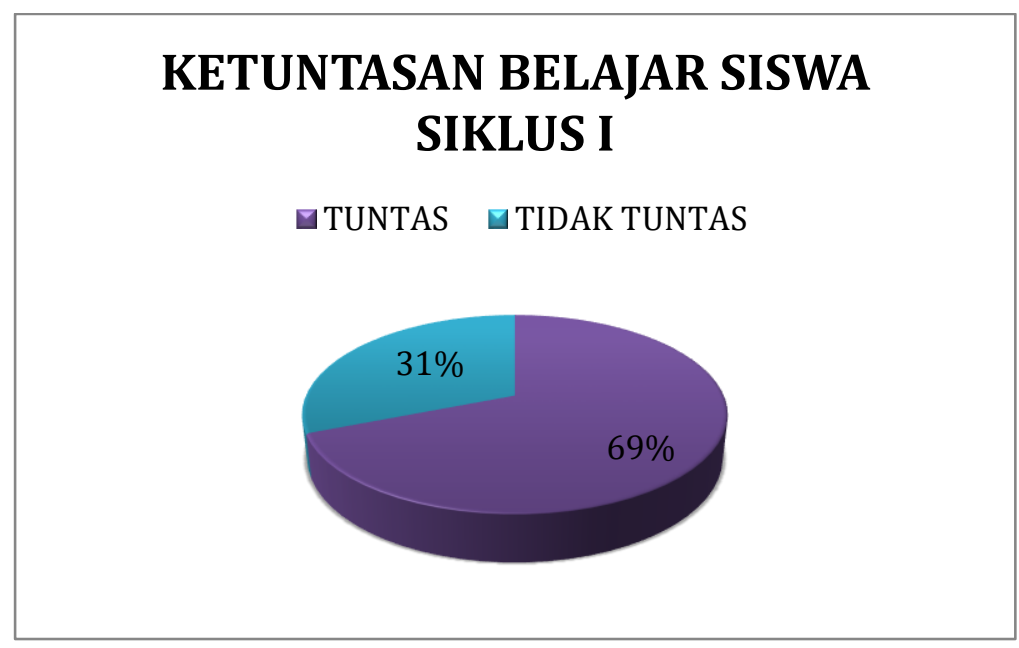

Gambar 2. Diagram Ketuntasan Nilai Siklus I

Berdasarkan grafik di atas menyatakan bahwa hasil belajar siswa dalam belajar kurang baik. Banyaknya anak yang berada pada kategori tidak tuntas yang berjumlah 8 orang dari 26 siswa, untuk itu perlu di adakan lanjutan pada siklus ke II. Pada akhir proses belajar mengajar siswa diberi tes formatif II dengan tujuan untuk mengetahui tingkat keberhasilan siswa dalam proses belajar mengajar yang telah dilakukan.

\section{Refleksi}

Dalam tahap refleksi ini peneliti dibantu oleh observer (Yetti, S.Pd. SD) melakukan musyawah diruang majelis guru. Adapun hasil diskusi dapat disimpulkan masalah yang terdapat selama proses pembelajaran berlangsung yaitu:
a. Siswa masih banyak yang ribut
b. Pengelolaan kelas belum sempurna
c. Pembagian kelompok yang kurang heterogen
d. Siswa masih belum mengerti dengan metode yang diterapkan guru
e. Masih banyak hasil belajar siswa yang belum mencapai target

Berdasarkan permasalahan yang ditemukan diatas, maka adapun langkah yang ingin diambil supaya tidak terulang lagi pada siklus berikutnya adalah sebgai berikut:

a. Membuat suasana tenang serta mengendalikan situasi kelas sebelum memulai pembelajaran 
b. Membagi kelompok secara rata

c. Menjelaskan terlebih dahulu model pembelajaran yang akan digunakan sebelum memulai pembelajaran

d. Memaksimalkan lagi pembelajaran sehingga hasil belajar siswa dapat meningkat dan mencapai target yang diinginkan.

\section{Siklus II}

\section{Perencanaan}

Pada tahap ini peneliti mempersiapkan perangkat pembelajaran yang terdiri dari silabus, RPP, media card, buku paket, LKS, Instrumen. Lalu menyiapkan dokumen onservasi, lembar aktivitas guru, perolehan hasil belajar siswa UH II.

\section{Pelaksanaan}

Pertemuan petama disiklus II dilaksanakan pada hari senin tanggal 26 Juli 2021 tahun pelajaran jam pelajaran 1-2 di kelas IV.B dengan jumlah siswa 26 orang. Adapun materi pembelajaran adalah indahnya kebersamaan. Pada kegiatan pembelajaran, peneliti melaksanakan berdasarkan rencana pelaksanaan pembelajaran (RPP). Guru memulai dengan memberikan apersepsi berupa mengingatkan kembali pelajaran terdahulu dan memberikan motivasi mengenai pentingnya mempelajari materi serta mengaitkannya dengan kegiatan sehari-hari. Pada pertemuan pertama siklus II ini penelitian mengacu pada prosedur yang telah ditetapkan mulai dari kegiatan pendahuluan, kegiatan inti dan kegiatan penutup.

Pertemuan kedua disiklus II dilaksanakan pada hari selasa tanggal 27 Juli 2021 jam pelajaran 3-4 di kelas IV.B dengan jumlah siswa 26 orang. Adapun materi pembelajaran pada pertemuan kedua ini adalah indahnya kebersamaan. Pada kegiatan pembelajaran, peneliti melaksanakan berdasarkan rencana pelaksanaan pembelajaran (RPP). Guru memulai dengan memberikan apersepsi berupa mengingatkan kembali pelajaran terdahulu dan memberikan motivasi mengenai pentingnya mempelajari materi serta mengaitkannya dengan kegiatan sehari-hari. Pada pertemuan kedua siklus II ini penelitian mengacu pada prosedur yang telah ditetapkan mulai dari kegiatan pendahuluan, kegiatan inti dan kegiatan.

\section{Observasi}

Pengamatan dilaksanakan bersamaan dengan pelaksaaan belajar mengajar yang dilakukan oleh observer. Adapun yang diamati oleh Observer meliputi pengelolaan belajar mengajar guru, aktivitas guru dan aktivitas siswa selama proses pembelajaran. Pada akhir proses belajar mengajar siswa diberi tes formatif dengan tujuan untuk mengetahui tingkat keberhasilan siswa dalam proses belajar mengajar yang telah dilakukan. Adapun data hasil penelitian pada siklus II adalah sebagai berikut: 
Tabel 3. Rekapitulasi Hasil Belajar Siswa Siklus II

\begin{tabular}{|c|c|c|c|}
\hline No & Nama Siswa & Nilai & Keterangan \\
\hline 1 & Achmad Rafa Saputra & 75 & Tuntas \\
\hline 2 & Aishka Vybie Azzahra & 80 & Tuntas \\
\hline 3 & Aliyah Nur Zahira & 95 & Tuntas \\
\hline 4 & Atania Miracle Christie Br S.Depari & 90 & Tuntas \\
\hline 5 & Bayu Andika Pratama & 90 & Tuntas \\
\hline 6 & Bintang Syafani & 95 & Tuntas \\
\hline 7 & Fairel Athariss Calief & 95 & Tuntas \\
\hline 8 & Gina Rinehart & 70 & Tuntas \\
\hline 9 & Irza Aldiansyah & 95 & Tuntas \\
\hline 10 & Kamilah Mutlihah & 85 & Tuntas \\
\hline 11 & Khalisa Hayu Nazeeha & 85 & Tuntas \\
\hline 12 & L. Berlian Natasya & 95 & Tuntas \\
\hline 13 & M. Fairusmansyur & 95 & Tuntas \\
\hline 14 & M. Nasuha.St & 90 & Tuntas \\
\hline 15 & Maria Ulfah & 67 & Tidak Tuntas \\
\hline 16 & Mei Syifa Irwansyah & 85 & Tuntas \\
\hline 17 & Monica Rachel Adelia Putri & 90 & Tuntas \\
\hline 18 & Muhammad Asri & 68 & Tidak Tuntas \\
\hline 19 & Mutiara Septiani & 90 & Tuntas \\
\hline 20 & Nathasya Aulia Putri & 85 & Tuntas \\
\hline 21 & Puspa Safatri Monik & 68 & Tidak Tuntas \\
\hline 22 & Rabbani Al Fathan & 90 & Tuntas \\
\hline 23 & Raka Rafael Manulang & 90 & Tuntas \\
\hline 24 & Raziq Zharfan Ramadhan & 90 & Tuntas \\
\hline 25 & Reysha Dwi Saputri & 80 & Tuntas \\
\hline 26 & Soraya Karisa Putri & 67 & Tidak Tuntas \\
\hline \multicolumn{2}{|c|}{ Jumlah } & 2205 & \\
\hline \multicolumn{2}{|c|}{ Rata-Rata } & 84,8 & \\
\hline \multicolumn{2}{|c|}{ KKM } & 70 & \\
\hline \multicolumn{2}{|c|}{ Jumlah Siswa Yang Tuntas } & \multicolumn{2}{|c|}{22 Orang $/ 85 \%$} \\
\hline \multicolumn{2}{|c|}{ Jumlah Siswa Yang Belum Tuntas } & \multicolumn{2}{|c|}{4 Orang $/ 15 \%$} \\
\hline
\end{tabular}

Dari tabel di atas dapat dijelaskan bahwa Pada siklus II ini di peroleh rata - rata hasil belajar siswa yaitu 84,8 dengan presentase $85 \%$ atau 22 siswa dari 2637 orang yang tuntas belajar. Hasil tersebut menunjukkan bahwa pada siklus II secara klasikal sudah baik, karena hanya 4 siswa yang memperoleh nilai kurang dari 70 atau hanya sebesar 15\% yang belum tuntas. Hal ini menunjukkan target ketuntasan sudah tercapai. Berdasarkan tabel nilai dan penjelasan nilai dari siklus II diatas dapat dilihat lebih jelas pada diagram dibawah ini: 


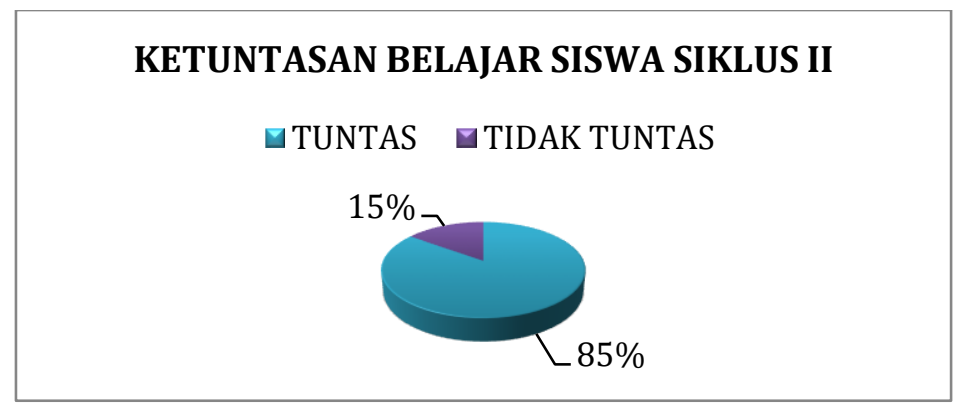

Gambar 3. Diagram Ketuntasan Nilai Siklus II

Berdasarkan grafik di atas menyatakan bahwa hasil belajar siswa dalam pembelajaran sudah baik. Banyaknya anak yang berada pada kategori ketuntasan yang berjumlah 22 orang dari 26 siswa, untuk itu karena sudah mencapai target yang diinginkan maka siklus ini tidak perlu dilanjutkan.

\section{Diskusi}

Ketuntasan Hasil belajar siswa, melalui hasil penelitian ini menunjukkan bahwa Model pembelajaran Jigsaw memiliki dampak positif dalam meningkatkan hasil belajar siswa. Hal ini dapat dilihat dari semakin mantapnya pemahaman peserta didik terhadap tema indahnya kebersamaan yang disampaikan guru. Ketuntasan belajar meningkat dari pra siklus 27\%, siklus I 69\%, dan siklus II 85\%. Pada siklus II ketuntasan belajar siswa secara klasikal telah tercapai. Untuk lebih jelasnya dapat dilihat pada gambar diagram ketuntasan belajar siswa dibawah ini.

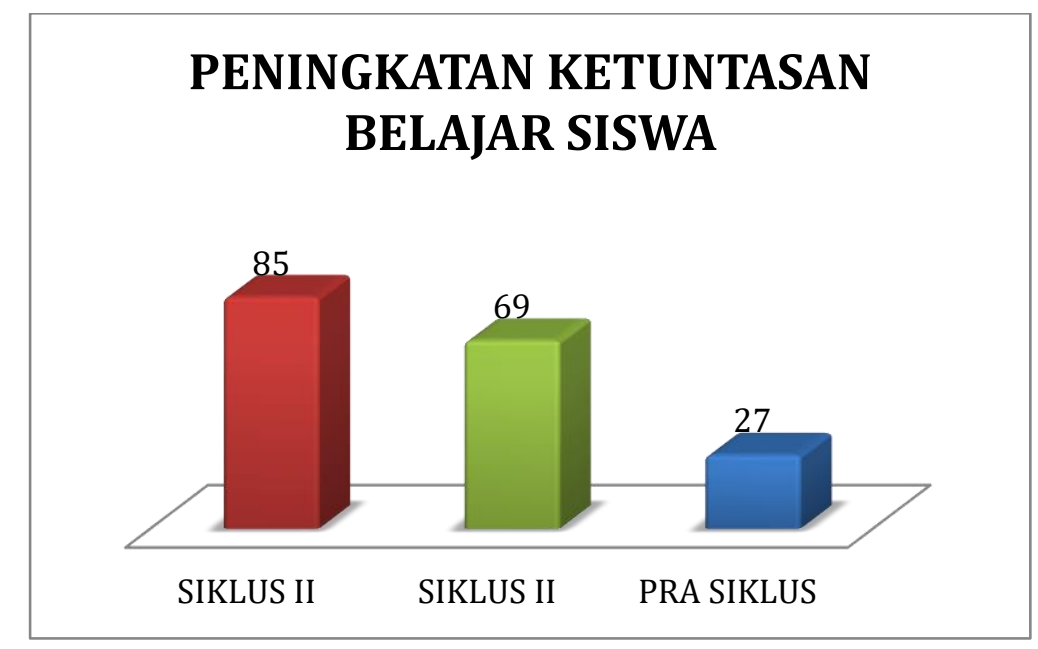

Gambar 4. Diagram ketuntasan hasil belajar siswa

\section{KESIMPULAN}

Dari hasil kegiatan pembelajaran yang telah dilakukan selama dua siklus, dan berdasarkan seluruh pembahasan serta analisis yang telah dilakukan dapat disimpulkan sebagai berikut:

1. Pembelajaran dengan Model Jigsaw memiliki dampak positif dalam meningkatkan hasil belajar siswa yang ditandai dengan peningkatan ketuntasan belajar siswa dalam setiap siklus, yaitu pra siklus (27\%), siklus I (69\%), siklus II (85\%).

2. Penerapan Model pembelajaran Jigsaw mempunyai pengaruh positif, yaitu dapat meningkatkan hasil belajar siswa yang ditunjukan dengan rata-rata jawaban siswa yang menyatakan bahwa 
siswa tertarik dan berminat dengan Model pembelajaran Jigsaw sehingga mereka menjadi termotivasi untuk belajar.

Dari hasil penelitian yang diperoleh dari uraian sebelumnya agar proses belajar pembelajaran lebih efektif dan lebih memberikan hasil yang optimal bagi peserta didik, maka saran sebagai berikut:

1. Untuk melaksanakan Model pembelajaran Jigsaw memerlukan persiapan yang cukup matang, sehingga guru harus mampumenentukan atau memilih topik yang benar-benar bisa diterapkan dengan Model pembelajaran Jigsaw dalam proses belajar mengajar sehingga diperoleh hasil yang maksimal.

2. Dalam rangka meningkatkan hasil belajar siswa, guru hendaknya lebih sering melatih peserta didik dengan berbagai model pengajaran, walau dalam taraf yang sederhana, dimana siswa nantinya dapat menemukan pengetahuan baru, memperoleh konsep dan keterampilan, sehingga peserta didik berhasil atau mampu memecahkan masalah-masalah yang dihadapinya.

3. Perlu adanya penelitian yang lebih lanjut, karena hasil penelitian ini hanya dilakukan di kelas IV.B SD Negeri 114/X Pandan Jaya.

4. Untuk penelitian yang serupa hendaknya dilakukan perbaikan-perbaikan agar diperoleh hasil lebih baik.

\section{REFERENSI}

Agus, Suprijono. 2010. Cooperative Learning. Yogyakarta. Pustaka Media.

Agus, Suprijono. 2012. Cooperative Learning: Teori dan Aplikasi Paikem. Yogyakrta: Pustaka Pelajar.

Al lamri, Ichas Hamid \& Tuti Istianti Ichas. 2006. Pengembangan Nilai Dalam Pembelajaran Pengetahuan Sosial Dasar. Jakarta: Departemen Pendidikan Nasional.

Anita Lie. (2007). Kooperatif Learning (Mempraktikkan Cooperative Learning di Ruang-ruang Kelas). Jakarta: Grasindo.

Dimyati. 2009. Belajar dan Pembelajaran. Jakarta: Rineka Cipta.

Hamalik, Oemar, 2004, Proses Belajar Mengajar, Jakarta : Bumi Aksara.

Lie, Anita. (1993). Cooperatif Learning. Jakarta: Grasindo

Nana Sudjana. (2002). Penilaian Hasil Proses Belajar Mengajar. Bandung: Remaja Rosdakarya.

Oemar Hamalik. 2012. Manajemen Pengembangan Kurikulum. Bandung: Remaja Rosdakarya.

Rusman. (2010). Model-model Pembelajaran (Mengembangkan Profesionalisme Guru Edisi Kedua). Jakarta: Raja Grafindo Persada.

Rusman. 2008. Model Pembelajaran Kooperatif Jigsaw. Diperoleh 17 april 2013 dari http://belajarpsikologi.com/model-pembelajaran-kooperatif-jigsaw/.

Slameto. (2010). Belajar dan Faktor-Faktor yang Mempengaruhinya. Jakarta: Rineka Cipta.

Slavin, Robert E. (2008). Cooperative Learning Teori, Riset, dan Praktik. Bandung: Nusa Media. 
Slavin, Robert E. (2009). Cooperative Learning (Teori, Riset, Praktik). Bandung: Nusa Media.

Suyono \& Hariyanto. (2012). Belajar dan Pembelajaran. Bandung: PT Remaja Rosdakarya Offset

Trianto. 2012. Model Pembelajaran Terpadu. (Jakarta: PT Bumi Aksara).

UU Sisdiknas No. 20 Tahun 2003 Pasal 1 Ayat 1

UUD 1945 Pasal 31 Ayat 5 